their lives in that position; the attitude is adopted occasionally and momentarily. Sloths do not hang head downwards, but back downwards; they are inverted pronogrades, and the effect of gravity on the contents of the thoracic duct can be little different from that in all four-footed pronograde mammals. When sloths do not hang downwards, their position is usually head upwards clinging to the trunk or sitting in the fork of a tree.

\section{Harrison Matthews}

The Old Rectory,

Stansfield, Suffolk.

Received November 7, 1968.

'Dumont, A. E., and Rifkind, K. M., Nature, 219, 1182 (1968).

\section{Early Campanian (Late Cretaceous) Mammals from Alberta, Canada}

Althoбgh the occurrence of fossil mammals in North American Upper Cretaceous rocks has long been known ${ }^{1}$, only since the application in 1956 of new collecting techniques ${ }^{2}$ have large samples of skeletal-especially dental-remains of Late Cretaceous mammals been recovered ${ }^{3}$. Important systematic studies have been based on these samples during the past decade. Maestrichtian (latest Cretaceous) assemblages from sites in New Mexico (W. Clemems, personal communication), Wyoming $^{3}$, Montana and Alberta $^{5}$ include several placental (Eutheria) orders, and many multituberculates (Allotheria) and didelphoid marsupials (Metatheria). Assemblages of late Campanian age in Montana ${ }^{6}$ and Alberta (unpublished results) are nearly as rich in multituberculates and marsupials, but are relatively poor in placentals, with only two orders (Insectivora and Deltatherida) represented.

In spite of this flurry of interest in Late Cretaceous mammals, there had been no significant chronological extension of the mammalian fossil record downwards in the North American Late Cretaceous since the discovery of fossil rnammals in the dinosaur-rich Oldman Formation (late Campanian), Alberta, more than $60 \mathrm{yr}$ ago. The stratigraphic interval between the late Campanian and the Albian (Early Cretaceous) of Texas, containing triconodonts, symmetrodonts, archaic (plagiaulacoid) multituberculates, and therian mammals of metatherianeutherian grade (but probably assignable to neither infraclass $\left.{ }^{7-9}\right)$, remained devoid of mammalian fossils.

In May 1968, I discovered isolated teeth of small fossil mammals in the continental sandstones and shales of the upper part of the Milk River Formation, southern Alberta, Canada ${ }^{10}$; these rocks are early Campanian in age ${ }^{11}$. The teeth occur in Verdigris Coulee, 18 miles east of the village of Milk River, Alberta, at three localities, with coordinates on file in the Department of Geology, University of Alberta, Edmonton. The mammalian teeth occur together with the fragmented skeletal parts of other vertebrates, including elasmobranchs (tecth), actinopterygian fishes, salamanders, lizards, turtles, champsosaurs, crocodiles and dinosaurs, and therefore occur in associations resembling those in younger mammalyielding Cretaceous rocks. Among the mammals, teeth of both multituberculates and marsupials are present; these are the oldest North American Late Cretaceous mammals known, and provide the earliest record of the infraclass Metatheria, order Marsupialia.

The multituberculate teeth are of ptilodontoid and taeniolabidoid type, and resemble most closely the later Cretaceous genera Mesodma Jepsen, Cimolodon Marsh and Cimolomys Marsh, but are not necessarily congeneric with them. The marsupial teeth, perhaps a third as abundant as those of multituberculates, are of didelphoid type, with tribosphenic molars, stylar shelves supporting numerous cusps on the upper molars, and closely approximated hypoconulid and entoconid cusps on the lower molars. At least four new genera of didelphoid marsupials are present, including the largest of North American Campanian mammals; two of these genera show no close resemblance in molar morphology to families of later Cretaceous marsupials, while two may pertain to the Didelphidae, already recorded from Cretaceous rocks younger than those of the Milk River Formation. The four genera, although possessing their own molar specializations, seem to exhibit a distinctly more primitive grade of molar evolution than do late Campanian and Maestrichtian marsupials, in that the Milk River forms lack molar cusp specializations for crushing and grinding of foodstuffs which are common in their younger Cretaceous relatives. The molar teeth of two additional kinds of marsupials in the Milk River Formation elosely resemble the late Campanian stagodontid Eodelphis Matthew and the late Campanian and Maestrichtian didelphid Alphadon Simpson, respectively. Systematic descriptions of these and other elements of this new and significant fossil assemblage are in preparation and will be published elsewhere.

I thank Mr L. Krishtalka and especially Mr L. A. Lindoe, whose careful work in the field secured the samples on which this communication is based. This work was supported by the University Research Fund and the Department of Zoology, University of Alberta.

\section{Richard C. Fox}

Departments of Geology and Zoology,

University of Alberta,

Edmonton. Alberta,

Canada.

Received October 21, 1968

${ }^{1}$ Van Valen, L., Amer. Mus. Novit., 2285, 1 (1967).

'McKenna, M., Curator, 3, 221 (1962)

${ }^{3}$ Clemens, W., Univ. Calif. Publ. Geol. Sci., 48, 1 (1983); 62, 1 (1966).

4 Sloan, R., and Van Valen, L., Science, 148, 220 (1965).

${ }^{s}$ Lillegraven, J., thesis, Univ. Kansas (1968).

- Sahni, A., thesis, Univ. Minnesota (1968).

7 Patterson, B., Fieldiana: Geol., 13, 1 (1956)

Slaughter, B., Postilla, 93, 1 (1965).

- Slaughter, B., Texas J. Sci., 20, 1 (1968).

${ }^{10}$ Russell, L., and Landes, R., Mem. Geol. Surv. Canada, 223 (1940).

${ }^{11}$ Williams, G., and Burk, C., in Geological History of Western Canada (edit. by McCrossan, R., and Glaister, R.), 169 (Alberta Soc. Petrol. Geol., Calgary, 1964)

\section{Incidence of R Factors among Gram Negative Bacteria in Drug-free Human and Animal Communities}

Transfer of drug resistance among Entcrobacteriaceae is mediated by cytoplasmic particles called $R$ factors which seem to consist of a transfer factor (RTF) coupled to genes which determine the drug resisting capacity of the bacterial host ${ }^{2}$. Although the origin of the intact $R$ factor is obscure ${ }^{3}$, there is some evidence that the transfer factors are widely distributed in the Enterobacteriaceae, and that they may on some occasions have picked up bacterial chromosome genes which determined drug resistance. Another possibility ${ }^{1}$ is that $\mathrm{R}$ factors arose in otherwise unrecognized plasmids during the course of mutations to a resistant form, but whatever mechanism is responsible, there is no doubt that $R$ factors are selected and maintained by drugs in the environment $t^{4}$. The finding ${ }^{5}$ of transmissible drug resistance in a strain of Escherichia coli lyophilized in 1946 may indicate that $\mathrm{R}$ factors were already present in pre-antibiotic cultures. The purpose of this investigation was to determine the incidence of $\mathrm{R}$ factors in intestinal Gram-negative bacteria 